\title{
O AGRONEGÓCIO E O PROBLEMA DO TRABALHO INFANTIL
}

\author{
Joel Orlando Bevilaqua Marin
}

\begin{abstract}
RESUMO
$O$ artigo buscar identificar e analisar as razões que levaram alguns setores do agronegócio a engajarem-se à luta pela erradicação do trabalho infantil no Brasil, desencadeada por organismos internacionais de defesa dos direitos da infância e da adolescência. Nossa hipótese é a de que a globalização da economia e a internacionalização dos direitos das crianças colocaram em evidência o problema do trabalho infantil. exigindo, portanto, a mobilização dos setores empresariais vinculados às cadeias produtivas do agronegócio no Brasil. O artigo está dividido em quatro seções inter-relacionadas. Na primeira, procura-se evidenciar a interferência de problemas sociais e trabalhistas no âmbito das atividades econômicas de setores do agronegócio, no atual contexto da globalização. Na seqüência, são estudados os principais investimentos da Organização das Nações Unidas, do Unicefe da Organização Internacional do Trabalho para internalizar os direitos da infância e as politicas de combate ao trabalho infantil, destacando suas repercussões no Brasil. Na terceira, são analisadas as estratégias adotadas por empresas vinculadas ao agronegócio para evitar a exploração da mão-de-obra infantil em suas cadeias produtivas. Por último, busca-se compreender as motivações que levaram os empresários do agronegócio a ingressarem na luta contra o trabalho infantil. Conclui-se que as empresas vinculadas ao agronegócio aderiram aos propósitos de combate ao trabalho infantil em virtude da internacionalização dos direitos das crianças e adolescentes, da inclusão de cláusulas sociais nos mercados internacionais, da intensificação da fiscalização do poder público, do crescimento de ações de responsabilidade social empresarial e do aumento da consciência dos consumidores.
\end{abstract}

PALAVRAS-CHAVE: Agronegócio; globalização; trabalho infantil; direitos de infância; exploração.

\section{INTRODUÇÃO}

No contexto da economia globalizada, as mercadorias, os serviços e os capitais circulam livremente, enquanto o mercado de trabalho tende a restringir-se aos limites territoriais das nações. Os governantes e as instituições da sociedade civil dos países desenvolvidos, preocupados com as conseqüências da concorrência comercial, passaram a acusar os países em desenvolvimento de produzir com baixos salários e com precária proteção social, valendo-se, inclusive, do uso do trabalho infantil, com o propósito de melhor colocar suas mercadorias nos mercados internacionais. Diante desses problemas, setores do agronegócio instalados no Brasil adotaram princípios e normas de conduta em suas atividades empresariais para evitar a incorporação de mão-de-obra infantil às cadeias produtivas de atuação. Pretendem, dessa forma, demonstrar um senso de responsabilidade social com as futuras gerações, na medida em que se vinculam à luta em defesa dos direitos das crianças e adolescentes.
Os direitos sociais das crianças e adolescentes adquiriram reconhecimento internacional em decorrência da atuação de organismos internacionais, como a Organização das Nações Unidas (ONU), o Fundo das Nações Unidas para a Infância (Unicef) e a Organização Internacional do Trabalho (OIT). Desde o fim da II Guerra Mundial, esses organismos vêm lutando pelo reconhecimento dos direitos da criança e empenhando grandes esforços para que tais direitos sejam ratificados pelas constituições dos mais diversos países. Em seus postulados, defendem que as crianças e os adolescentes são pessoas em condições especiais de desenvolvimento e sujeitos de direitos próprios, com necessidades de proteção específicas e com direitos de capacitação adequada, antes de propriamente interagirem no mercado de trabalho.

O objetivo deste trabalho é analisar as razões da mobilização dos empresários ligados ao agronegócio no combate ao trabalho infantil, mobilização essa desencadeada a partir da década 
de 1990, no contexto da globalização da economia. Nossa hipótese é que a globalização da economia e a internacionalização dos direitos das crianças colocaram em evidência o problema do trabalho infantil, exigindo, por conseqüência, a mobilização dos setores empresariais vinculados às cadeias produtivas do agronegócio no Brasil. A partir de análise bibliográfica e documental, procurou-se compreender as interfaces entre os processos da globalização e da internacionalização dos direitos da infância para avaliar as motivações da organização social do empresariado do agronegócio no combate ao trabalho infantil em suas cadeias produtivas, com vistas a atender às imposições do mercado exterior e aos princípios da responsabilidade social empresarial.

$\mathrm{O}$ artigo está dividido em quatro seções interrelacionadas. Na primeira, procura-se evidenciar a interferência de problemas sociais e trabalhistas no âmbito das atividades econômicas de setores do agronegócio, no atual contexto da globalização. Na seqüência, são estudados os principais investimentos da ONU, do Unicef e da OIT para internalizar os direitos da infância e as políticas de combate ao trabalho infantil, destacando suas repercussões no Brasil. Na terceira, são analisadas as estratégias adotadas por empresas vinculadas ao agronegócio para evitar a exploração da mãode-obra infantil em suas cadeias produtivas. Por último, busca-se compreender as motivações que levaram os empresários do agronegócio a ingressar na luta contra o trabalho infantil.

\section{AGRONEGÓCIO, GLOBALIZAÇÃO E PRO- BLEMAS SOCIAIS}

O agronegócio, constituído pela interdependência dos capitais industriais, agrícolas, financeiros, comerciais e de serviços, deve ser compreendido no contexto dos problemas contemporâneos, marcados pelo fenômeno da globalização. No contexto atual, segundo Mundt (1998), a vida econômica dos países e regiões experimenta transformações consideráveis, com reformas que buscam criar condições para a expansão de uma nova forma de organizar as relações capitalistas. As diversas empresas que integram as cadeias produtivas do agronegócio também passaram por mudanças e reestruturações para adequar-se às novas dinâmicas impostas pelo desenvolvimento do capital.

Em linhas gerais, a globalização guarda estreitas relações com a formação de blocos econômicos, os ajustes estruturais, a liberação do comér- cio e a desregulamentação da economia. Como nova etapa do desenvolvimento do capitalismo, a globalização impulsionou o movimento de capitais para além das fronteiras dos territórios dos países, o que reduziu os poderes dos estados-nação. Os países ricos e instituições internacionais como o Fundo Monetário Internacional (FMI) e o Banco Interamericano de Desenvolvimento (BID) impuseram programas de ajuste estrutural para a liberalização do comércio e do investimento estrangeiro, criando condições para a atuação de grandes corporações empresariais internacionais, ligadas ao capital industrial, comercial e, especialmente, financeiro, que operam em escala mundial. Essas empresas promovem profundas transformações tecnológicas nos campos da informática, da comunicação, da biotecnologia e dos transportes. Em decorrência desse processo, houve uma reorganização das regiões produtivas, acentuando a separação entre os espaços de produção e de consumo das mercadorias. Na divisão internacional do trabalho, os países desenvolvidos tendem a dominar a produção da "tecnologia de ponta", enquanto os países em desenvolvimento tornam-se consumidores dessa tecnologia e produtores de gêneros alimentícios (TEUBAL, 1998).

A globalização também promoveu uma reestruturação produtiva, implicando a terceirização das atividades produtivas, a segmentação da produção e a formação de redes de empresas, a qual intensifica as relações de interdependência dos setores industrial, agrícola, financeiro, comercial e de serviços que, por sua vez, integram as mais diversas cadeias produtivas do agronegócio (MAZZALI, 2000). Esse processo implicou também na flexibilização das relações de trabalho, na redução dos direitos trabalhistas e na ampliação dos processos de exclusão social, em decorrência do aprofundamento do desemprego estrutural, da concentração de renda e do rebaixamento dos salários. Segundo Rubio (2001), para a maioria dos agricultores familiares latino-americanos, a globalização representou o aprofundamento da exclusão social. Em contrapartida, os agricultores familiares que permanecem integrados às cadeias produtivas do agronegócio são explorados economicamente e submetidos às exigências tecnológicas e aos padrões de qualidade e quantidade determinados pelos mercados globalizados.

No contexto da globalização, há uma tendência de unificar os aparatos jurídicos que regulamentam a organização das trocas comerciais en- 
tre os países, estabelecidos em tratados internacionais como o Acordo da Organização Mundial do Comércio (OMC), que são resultantes das Rodadas do Uruguai de negociações comerciais, celebradas em 1986 e 1994, e do Acordo Geral sobre Tarifas Aduaneiras e Comércio, de 1996. Não raramente, esses acordos tornam-se barreiras para a realização das trocas comerciais internacionais, algumas relacionadas à questão do trabalho, com o propósito de combater o "dumping" social. De acordo com Schmidt, Sousa e Lima, o dumping "é definido como sendo a fixação do preço de exportação, para determinado bem e país, a um nível inferior ao seu valor normal" (SCHMIDT, SOUSA \& LIMA, 2006, p. 3). O dumping social está associado ao rebaixamento dos preços dos produtos de exportação, decorrente da super-exploração de trabalhadores, envolvidos em relações de trabalho degradantes ou escravas, bem como do emprego de crianças.

Como sustenta Rogalski (1997), no contexto da economia globalizada, as mercadorias, os serviços e os capitais circulam livremente entre os países, enquanto a migração dos trabalhadores tem sofrido sérias restrições, impostas especialmente pelos Estados Unidos e pelos países europeus. A busca de mão-de-obra mais barata, por empresas multinacionais, em determinado país, pode destruir os empregos de outros, criando uma concorrência entre os trabalhadores num plano mundial. Por isso, os países desenvolvidos, preocupados com as conseqüências da concorrência comercial, passaram a acusar os países subdesenvolvidos de produzirem com baixos salários e com precária proteção social, ou seja, de fazerem dumping social para melhor colocar suas mercadorias nos mercados internacionais. Assim, desde 1993, dirigentes de nações desenvolvidas, especialmente da França e dos Estados Unidos, propugnam a criação de instrumentos de proteção de defesa do comércio em relação aos países subdesenvolvidos. Surgiu, então, a idéia de uma cláusula social que estabelece condições sociais para o comércio, introduzida nos acordos de comércio internacional. Bem elaborada, a idéia apresentou-se com roupagem atraente e com objetivos aparentemente nobres, na medida em que pretendia impor às empresas o estabelecimento de salários dignos. Na realidade, essa cláusula social esconde seus reais interesses, puramente mercantis, porque, antes de tudo, trata de limitar a concorrência de produtos originários dos países do
Terceiro Mundo. Constitui-se, portanto, numa barreira comercial entre os países do Norte e do Sul para conter os efeitos advindos com a concorrência entre os trabalhadores em escala mundial.

As cláusulas sociais inseridas nos acordos comerciais internacionais contemplam restrições à exploração do trabalho infantil. Segundo Bonnet (1998), alguns setores empresariais querem proteger-se da concorrência desleal, promovida por aquelas empresas que exploram seus trabalhadores ou que se transferem para outros países, em busca de mão-de-obra mais barata e com menor proteção dos direitos trabalhistas, previdenciários e sociais. Tais setores juntam-se ao coro da luta contra o trabalho infantil, não por razões necessariamente semelhantes, como as organizações sindicais e humanitárias que procuram fazer pressão sobre aquelas empresas que não respeitam seus trabalhadores, nem observam as convenções internacionais que tratam de normatizar o mundo do trabalho.

Como demonstram Sastre e Mayer (1996), os trabalhadores das minas de carvão da Inglaterra, organizados politicamente nos sindicatos, investiram na realização de pesquisas e documentários com o propósito de denunciar publicamente a exploração desumana de crianças nas minas de carvão na Colômbia, sob o pretexto de que isso criaria uma concorrência desleal e colocaria em risco seus empregos. Também vale mencionar a pressão da Confederação Internacional das Organizações Sindicais Livres (Ciosl) para a inclusão de uma cláusula social nos acordos da $\mathrm{OMC}$ e noutros acordos comerciais internacionais, no intuito de contemplar a garantia da liberdade sindical e o direito de negociação coletiva, as normas da idade mínima de admissão ao emprego, a não-discriminação e o trabalho forçado.

Essa proposta, elaborada durante o XIV Congresso Mundial da Ciosl, fazia referência a um conjunto de documentos da OIT, elaborados no intuito de enfrentar o problema do trabalho infantil-especialmente na América Latina, Ásia e África - e devolver às crianças o direito de brincar, evitando, dessa forma, o desemprego dos trabalhadores adultos (INTERNATIONAL CONFEDERATION OF FREE TRADE UNIONS, 1996).

Num contexto de profundas transformações mundiais, os empresários de diversas cadeias produtivas do agronegócio mobilizaram-se para en- 
caminhar resoluções ao problema do trabalho infantil. Diante da ampla exposição nos meios de comunicação de massa e da intensificação de campanhas, instituídas pelos organismos internacionais de defesa dos direitos humanos e da infância, os empresários não podiam permanecer indiferentes ante a exploração "desumana" de trabalhadores precoces. Então, o Estado, os empresários e a sociedade deparavam-se com leis e concepções sobre a infância, reconhecidas internacionalmente, sintetizadas em um longo processo de construção social.

\section{A INTERNACIONALIZAÇÃO DOS DIREI- TOS DA INFÂNCIA}

A globalização não está restrita aos aspectos econômicos, produtivos e tecnológicos, mas tende a configurar-se também no âmbito dos direitos humanos. Desde o final da II Guerra Mundial, a ONU, o Unicef e a OIT estabeleceram discussões sistemáticas, acompanhadas de programas de ações, com o propósito de eliminar o trabalho infantil em todos os quadrantes do planeta. Os investimentos dessas organizações devem ser entendidos como processos de internacionalização dos direitos e das concepções de infância. De acordo com Bobbio (2004), uma nova ordem mundial foi estabelecida com a universalização dos direitos humanos, denominada "era dos direitos", a partir do momento em que organizações internacionais vieram a construir e difundir novas concepções dos direitos do homem e novos papéis para os Estados. O marco fundamental foi delimitado na Declaração Universal dos Direito do Homem, promulgada em 10 de dezembro de 1948, na Assembléia Geral das Nações Unidas.

Quando a Declaração Universal dos Direitos Humanos afirma que "[t]odos os homens nascem livres e iguais em dignidade e direitos", significa, segundo Bobbio, que os "homens são livres e iguais por natureza, mas, de fato, os homens não nascem livres e nem iguais" (BOBBIO, 2004, p. 49). Os homens "são livres e iguais apenas em relação a um nascimento ou natureza ideais" (ibidem), já que "a liberdade e a igualdade dos homens não são um dado de fato, mas um ideal a perseguir; não são uma existência, mas um valor; não são um ser, mas um dever ser" (ibidem). Dessa forma, o desafio para os organismos internacionais foi converter esses valores humanos em direitos positivados, isto é, em direitos garantidos na constituição do Estado de direito, e generalizá- los para todos os cidadãos, independentemente do país em que vivem. O propósito era construir um Estado de direito, compreendido como o Estado de cidadãos, no qual todas as pessoas sejam portadoras de direitos, independentemente de origem socioeconômica, nacionalidade, religião, cor, sexo e idade. Em suma, os organismos internacionais, por meio de seus intelectuais orgânicos, tratavam de garantir e generalizar direitos para todos os cidadãos do planeta.

Além disso, segundo Bobbio (idem), os organismos partiram para uma especificação dos direitos dos cidadãos cada vez mais acentuada dos sujeitos titulares dos direitos, a partir da constatação da existência de diferenciações de gênero, de fases da vida e dos estados normais e excepcionais da existência humana. Ou seja, as legislações encaminharam-se para o reconhecimento da existência de diferenças entre homens e mulheres, entre crianças, jovens, adultos e idosos, entre as pessoas consideradas normais e doentes ou entre deficientes e doentes mentais. O reconhecimento das diferenças constituiu-se numa inovação no que se refere aos direitos da criança. O desenvolvimento ou o amadurecimento da Declaração Universal dos Direitos do Homem gerou um documento interpretativo específico para a infância, expressada na Declaração Universal dos Direitos da Criança, promulgada pela Assembléia Geral das Nações Unidas, no dia 20 de novembro de 1959.

Essa Declaração afirma que a criança, em decorrência de sua imaturidade física e mental, requer cuidados especiais, antes e após o nascimento. Portanto, cabe à família, ao Estado e à sociedade prestar o melhor dos esforços para garantirlhe o desenvolvimento de modo sadio, normal e em condições de liberdade. Condensada em dez princípios, a Declaração afirma que todas as crianças são credoras de direitos à igualdade, sem distinção ou discriminação de raça, cor, sexo, língua, nacionalidade, origem social ou posição econômica; à especial proteção para seu desenvolvimento físico, mental e social; a um nome e uma nacionalidade, desde seu nascimento; à previdência social, saúde, alimentação e recreação; ao tratamento, educação e cuidados especiais para as crianças incapacitadas física, mental ou socialmente; ao amor e à compreensão dos pais e da sociedade; à educação gratuita e ao lazer; à proteção, atendimento e socorro prioritário em casos 
de catástrofes e à proteção contra todos os atos que possam suscitar qualquer forma de discriminação.

Para efeito desta pesquisa, vale ressaltar o nono princípio da Declaração Universal dos Direitos da Criança, atinente à exploração da força de trabalho: "a criança gozará de proteção contra quaisquer formas de negligência, crueldade e exploração. Não será jamais objeto de tráfico, sob qualquer forma. Não será permitido à criança empregar-se antes da idade mínima conveniente; de nenhuma forma será levada a ou ser-lhe-á permitido empenhar-se em qualquer ocupação ou emprego que lhe prejudique a saúde ou a educação ou que lhe interfira no seu desenvolvimento físico, mental ou moral".

A Declaração defende que as crianças são sujeitos singulares em relação adultos e, dada a sua imaturidade física e intelectual, devem ser protegidas contra as formas de exploração de sua força de trabalho. A partir desse pressuposto, as organizações internacionais partiram para uma luta sistemática com o objetivo de construir uma concepção universalista da infância, investindo constantemente na promoção, no controle e na garantia dos direitos das crianças. Em face das dificuldades de universalizar as concepções e os aparatos legais, atinentes à infância e ao trabalho infantil, coube à OIT a elaboração de um conjunto de leis e práticas para estruturar as relações sociais de trabalho, institucionalizadas em convenções, recomendações, normativas, critérios de fiscalização, relatórios e pesquisas. Todos os investimentos, seja no campo da elaboração de um aparato jurídico, seja no campo da proposição de políticas públicas, tinham como objetivo a construção de uma concepção consensual que deveria ser difundida em todos os países. Com essa missão, a OIT assumiu campanhas internacionais para combater o trabalho infantil e, ao mesmo tempo, impor penalidades e constrangimentos aos países que se recusavam a referendar seus documentos ou que não cumpriam seus postulados. Desde então, o marco da atuação da OIT esteve referenciado pela proibição do emprego de crianças e adolescentes que não tenham completado a escolarização básica, nem alcançado uma idade mínima para o ingresso no trabalho.

Na Conferência Internacional do Trabalho, realizada em 1973, a OIT aprovou a Convenção n. 138, que estabelece a idade mínima de admis- são a emprego ou a trabalho, tendo como seu corolário a recomendação n. 146 . O artigo $2^{\circ}$ da Convenção 138 recomenda aos países-membros que a idade mínima "não será inferior à idade de conclusão da escolaridade compulsória ou, em qualquer hipótese, não inferior a quinze anos". Nesse momento, os intelectuais orgânicos da OIT estavam certos de que a eliminação do trabalho das crianças seria possível e não tardaria. De acordo com a visão dominante, o trabalho infantil era um mal que deveria ser eliminado, com a aplicação progressiva da legislação. Esses agentes percebiam a Convenção n. 138 como uma espécie de tecnologia de ponta no domínio político e social, que transformaria a sociedade num processo progressivo, à medida que os países ratificassem-na. Essa Convenção refletia, de certa forma, o otimismo em torno das políticas públicas proporcionadas pelo estado de bem-estar social nos países ocidentais, sobretudo no que tange à ampliação e melhoria das redes de ensino público para as crianças e adolescentes. Porém, a promulgação da Convenção não trouxe os resultados esperados, pois em 1979 o departamento de estatísticas da OIT anunciou que 56 milhões de crianças com menos de 15 anos de idade estavam incorporadas no trabalho nos mais diversos países, especialmente no Terceiro Mundo (RODGERS \& STANDING, 1983).

A partir da constatação da permanência de elevados índices de exploração do trabalho infantil nos países subdesenvolvidos, os organismos internacionais deixaram de acreditar apenas na força da abordagem repressiva das legislações e passaram a defender a necessidade de institucionalização de políticas públicas. Em 1979, a ONU declarou o Ano Internacional da Criança, proporcionando enorme publicidade sobre as condições de vida das crianças nas diversas partes do planeta. A comunidade internacional descobriu não somente que as crianças sofriam com as doenças infantis, a fome, a desnutrição, a falta ou precariedade de habitação, de saneamento básico e de água potável, a inexistência ou debilidade do sistema escolar, mas também que eram vítimas da exploração e violência dos adultos, como agressões no trabalho, escravidão, violência sexual, venda, tortura, abandono, guerra e prisão em condições intoleráveis.

No plano internacional, a década de 1980 ficou marcada pela discussão e implementação da Convenção dos Direitos da Criança, que provo- 
cou verdadeiras transformações, com aplicações inclusive para as situações do trabalho infantil. Os diversos organismos internacionais situaram o trabalho infantil no âmbito da violação do conjunto dos direitos da criança, bem como da exploração econômica, ampliando a análise da problemática. Em primeiro lugar, relacionaram o trabalho às graves implicações na formação da pessoa humana e da sociedade, que resultava na dilapidação prematura da força de trabalho. Em segundo lugar, o trabalho infantil não era percebido simplesmente como um problema de uma relação pessoal, estabelecida entre a criança e seu empregador ou seus pais, mas uma questão universal do desenvolvimento econômico, político e social (BONNET, 1999).

A convicção de que a resolução do problema do trabalho infantil passaria pela promulgação e aplicação de modernas legislações foi progressivamente substituída pelas propostas orientadas no sentido da institucionalização de políticas públicas no âmbito dos países. Então, os organismos internacionais propuseram-se a defender programas de melhoria da qualidade de vida da população, por meio da ampliação dos serviços públicos de educação, saúde, moradia e geração de emprego (BEQUELLE \& BOYDEN, 1990). Nota-se que houve uma mudança significativa na compreensão e no encaminhamento do problema do trabalho infantil, na medida em que a abordagem legalista perdeu a centralidade face ao crescimento da importância da institucionalização de políticas públicas, com vistas a garantir a melhoria das condições de vida das crianças e de suas famílias.

Juntamente aos investimentos de sensibilização da comunidade internacional, a ONU publicou, em 1989, a Convenção sobre os Direitos da Criança, inspirada na Declaração dos Direitos Universais do Homem, nos Pactos Internacionais de Direitos Humanos e na Declaração Universal dos Direitos das Crianças. No que concerne ao trabalho, o artigo 32 da Convenção defende que "os Estados Partes reconhecem o direito da criança de estar protegida contra a exploração econômica e contra o desempenho de qualquer trabalho que possa ser perigoso ou interferir em sua educação, ou que seja nocivo para sua saúde ou para seu desenvolvimento físico, mental, espiritual, moral ou social”. Para assegurar a aplicação desse artigo, recomendou aos Estados Partes a adoção de medidas legislativas, administrativas, sociais e edu- cacionais, para o estabelecimento da idade mínima para o ingresso em empregos, a regulamentação apropriada relativa a horários e condições de emprego, bem como as penalidades e sanções apropriadas.

No entanto, a legislação brasileira não comungava com as concepções defendidas pelos organismos internacionais. Sob o enfoque da integração social administrada, a legislação e as políticas públicas até então instituídas indicavam a incorporação prematura no mundo do trabalho e/ou a profissionalização de crianças e adolescentes como estratégias capazes de concorrer com as formas fáceis de agregação à marginalidade. As concepções internacionais dos direitos das crianças e adolescentes somente tiveram repercussões na elaboração da Constituição Brasileira de 1988, como se pode constatar no artigo 227: "É dever da família, da sociedade e do Estado assegurar à criança e ao adolescente, com absoluta prioridade, o direito à vida, à saúde, à alimentação, à educação, ao lazer, à profissionalização, à cultura, à dignidade, ao respeito, à liberdade e à convivência familiar e comunitária, além de colocá-los a salvo de toda a forma de negligência, discriminação, exploração, crueldade e opressão".

Empenhado na discussão e elaboração de uma lei ordinária que regulamentasse as conquistas introduzidas na nova Carta Constitucional e, conseqüentemente, revogasse o aparato legal vigente durante o período do regime militar, o Fórum Permanente de Entidades Não-Governamentais de Defesa dos Direitos da Criança e do Adolescente conseguiu articular diversas instituições sociais comprometidas com a causa da infância e adolescência. Esse movimento social obteve conquistas no âmbito das discussões e elaboração de uma legislação específica para a infância e a adolescência, que confluiu na promulgação do Estatuto da Criança e do Adolescente (ECA), no dia 13 de julho de 1990. Esse documento significou um salto qualitativo não apenas na concepção dos direitos de cidadania da população infanto-juvenil, mas também pela proposição do reordenamento político-institucional. Com isso, abriram-se maiores espaços de participação da sociedade civil na discussão, na decisão e no controle das políticas públicas voltadas para crianças e adolescentes. Tanto no processo de elaboração como em sua concepção, o Estatuto representou uma ruptura na tradição nacional e latino-americana, porque 
alterou o caráter autoritário e corporativo da legislação e das políticas públicas orientadas para a infância e adolescência (OLIVEIRA, 1994; MÉNDEZ, 1998).

Os direitos à proteção no trabalho e à profissionalização, previstos no Estatuto da Criança e do Adolescente, estão fundamentados nas doutrinas da ONU e nas convenções da OIT. No capítulo V, o ECA estabeleceu a proibição do trabalho aos menores de 14 anos, salvo na condição de aprendizes, entre os 12 e 14 anos de idade. A aprendizagem é considerada como a formação técnica e profissional ministrada em conformidade com as diretrizes e bases da legislação da educação. O ECA também definiu, no capítulo IV, que a educação escolar deve ser garantida pelo Estado, pela família e pela sociedade, para o desenvolvimento da criança e do adolescente, o preparo para o exercício da cidadania e a qualificação para o trabalho.

Fica evidente que a legislação reconheceu como problema a inserção precoce no mundo do trabalho, em razão de seus efeitos perversos sobre a saúde, sobre o desenvolvimento físico e sobre a escolarização, cujos futuros desdobramentos inevitavelmente ficarão marcados pelas precariedades social e produtiva (MARIN, 2005). Mas, paralelamente ao avanço da legislação, que garantiram direitos e deveres para crianças e adolescentes, expandia-se a exploração da mão-de-obra infantil. Em 1995, segundo dados do Instituto Brasileiro de Geografia e Estatística (IBGE), 7316 636 crianças e adolescentes trabalhavam para garantir sua própria sobrevivência, comprometendo o seu desenvolvimento físico e intelectual. $\mathrm{Na}$ verdade, o problema da exploração da mão-deobra infantil assumia dimensões internacionais. Uma pesquisa da OIT, lançada durante a Conferência Internacional do Trabalho de 1998, indicava a existência de 250 milhões de crianças trabalhadoras, com menos de 15 anos. Em determinados contextos, as crianças eram exploradas em "formas intoleráveis", tornando-se necessária a “erradicação imediata” (OIT, 1997, p. 8).

Em 1991, o governo alemão destinou à OIT uma soma de 50 milhões de marcos, por um período de cinco anos, para manter um programa específico de ação sobre o trabalho infantil. Esse incentivo possibilitou o lançamento do Programa Internacional de Erradicação do Trabalho Infantil (IPEC), que se tornou o mais importante progra- ma de ação no plano mundial de combate ao trabalho infantil. O programa foi lançado no ano de 1992 em apenas cinco países, dentre eles o Brasil. E, ao final dessa década, já estava instituído em mais de quarenta países. Da mesma forma, o programa suscitou interesse dos países em fazer dotações de recursos: começou com a Alemanha e chegou a uma dezena de países colaboradores. A característica principal do IPEC é atuar por meio de projetos definidos sobre as realidades locais e sob a responsabilidade dos atores locais, privilegiando aqueles que têm contato direto com as crianças trabalhadoras. Isso resultou na mobilização de organizações não-governamentais e instituições públicas para reunir forças de combate às piores formas de exploração do trabalho infantil (BONNET, 1999).

Paralelamente, a OIT investiu em pesquisas sobre os impactos globais do trabalho infantil, seja no plano mundial, seja no plano nacional. A partir dos dados de pesquisa, essa instituição estabeleceu campanhas educativas, por intermédio do rádio, da televisão e das numerosas publicações, convocando cada cidadão a agir, dentro do seu domínio, em prol da causa do combate ao trabalho infantil. O propósito central era articular redes de ação, interligando agentes públicos e privados, para retirar as crianças do trabalho e inseri-las nas políticas e programas educativos. Enfim, todos os documentos e investimentos do IPEC apostam nas estratégias de prevenção para o combate do trabalho infantil no mundo contemporâneo.

A proposição de um projeto de lei de autoria de Tom Harkin ${ }^{1}$, apresentado ao Senado Americano em agosto de 1992, tornou-se um fato de grande repercussão internacional. A Harkim Bill propõe sanções aos países exportadores que, em alguma etapa da cadeia produtiva, empregam a mão-deobra infantil. $\mathrm{O}$ efeito imediato dessa lei foi colocar o governo norte-americano na posição da linha de frente do combate ao trabalho infantil. Essa lei provocou um longo debate, que confluiu na inserção de cláusulas sociais nas relações comerciais internacionais, questão que foi incorporada em 1995 pela Organização Mundial do Comércio (OMC). O tratado da OMC não se restringe ao trabalho infantil, mas concerne aos direitos dos trabalhadores em geral, porém, deve-se conside-

1 Senador norte-americano do Partido Democrata, representante do Estado de Iowa. 
rar que a exploração econômica da infância é questão que sensibiliza mais facilmente a opinião pública. A Harkin Bill provocou um verdadeiro choque de amplitude internacional, na medida em que obrigou os Estados exportadores a colocar em suas agendas políticas e econômicas a questão do trabalho infantil. Não se tratava tão-somente da elaboração de programas para melhor distribuição da renda nacional ou de algo restrito ao domínio das questões internas de cada país, como tradicionalmente fora abordada a questão do trabalho infantil. Como novidade internacional, a lei enfocou o trabalho infantil dentro do contexto das relações comerciais de extrema competitividade, no sentido de assegurar o controle de partes significativas do mercado, no contexto da economia globalizada. Ou seja, as questões sociais, especialmente aquelas relacionadas aos direitos da infância, entraram na órbita das trocas comerciais entre os países (BONNET, 1998; 1999).

No Brasil, após a promulgação do ECA, cresceu a luta sistemática para a prevenção e erradicação do trabalho infantil. Nos primeiros anos da década de 1990, diversos agentes sociais, públicos e privados, embasados em propósitos de condenação das formas perversas de agregação de crianças e adolescentes ao trabalho, criaram espaços e situações para o debate, a conscientização e a mobilização da sociedade em torno desse problema social. Conseqüentemente, instituíram-se políticas sociais destinadas às crianças e aos adolescentes vinculados ao trabalho assalariado, o que acenava com a interdição dessas atividades econômicas ilegais e indicava o encaminhamento desses agentes à escola, sob o pressuposto de que o lugar de criança é na escola e não no trabalho.

Com o apoio de organizações de cooperação internacionais, especialmente da OIT e do Unicef, o governo brasileiro instituiu, em 1992, o Programa de Erradicação do Trabalho Infantil (PETI), com o objetivo de proteger a população infantojuvenil, entre 7 e 14 anos de idade, vulnerabilizada pela exploração, pobreza e exclusão social. O programa foi introduzido nas atividades que configuravam situações de extrema exploração, a exemplo das carvoarias e ervais do Mato Grosso do Sul, dos canaviais de Pernambuco e do Rio de Janeiro, do sisal e das pedreiras da Bahia. Com a concessão de auxílio mensal às famílias, por meio da Bolsa Criança Cidadã, o programa tratava de afastar as crianças e adolescentes do mercado de trabalho e de criar condições para sua permanência na escola. Além disso, procurava incentivar a apropriação de novos conhecimentos por meio de atividades culturais, esportivas e de lazer, no período complementar ao da jornada de ensino regular. Ao final da década de 1990, o PETI foi ampliado para outros estados e para outras atividades produtivas em que havia exploração de crianças (BRASIL, 1998; 1999). Somou-se ainda o Programa Bolsa-Escola Federal, instituído em 2001, com o mesmo objetivo de estimular a matrícula e a permanência de crianças de 7 a 14 anos de idade na escola, mediante a vinculação de uma renda mensal.

No campo jurídico, também, ocorreu uma importante mudança relacionada ao problema do trabalho infantil. A Emenda Constitucional n. 20, promulgada em 1998, no artigo 7 , inciso 33 , estabeleceu "a proibição de trabalho noturno, perigoso ou insalubre a menores de 18 anos e de qualquer trabalho a menores de 16 anos, salvo na condição de aprendiz, a partir de 14 anos". A nova lei ampliou o período de dependência da criança e do adolescente em relação ao adulto, ao determinar uma idade mais elevada para o ingresso no trabalho e a obrigatoriedade do estudo, pelo menos até os 14 anos de idade.

Com a aprovação da Emenda Constitucional n. 20, o Brasil ratificou, em junho, de 2001 a Convenção n. 138 da OIT, comprometendo-se "a seguir uma política nacional que assegure a efetiva abolição do trabalho infantil e eleve, progressivamente, a idade mínima de admissão a emprego ou a trabalho a um nível adequado ao pleno desenvolvimento físico e mental do jovem". Nesse sentido, o Brasil comprometeu-se com a comunidade internacional a não empregar crianças e adolescentes com idade inferior a 16 anos de idade, a não ser na condição de aprendiz, depois dos 14 anos. Em setembro de 2000, o Brasil havia ratificado a Convenção n. 182, que proíbe as formas intoleráveis de trabalho infantil: escravidão e práticas similares, exploração sexual e comercial de crianças, participação em atividades ilegais, como tráfico de drogas e trabalhos que afetem a saúde, segurança ou a moralidade das crianças. Juntamente com a ratificação das Convenções da OIT, o país tratava de valorizar o processo de escolarização básica. A obrigatoriedade da escolarização e o cumprimento da legislação ope- 
ram, assim, como marcos referenciais fundamentais para criar uma concepção consensual e orientar as ações de campanhas destinadas à erradicação do trabalho infantil.

\section{A MOBILIZAÇÃO DE SETORES EMPRE- SARIAIS VINCULADOS AO AGRONE- GÓCIO}

Na nova ordem mundial, a produção de mercadorias por crianças para a exportação, a transferência de certas empresas para países que recorrem ao uso da força de trabalho infantil, a ampliação das campanhas educativas acerca do problema do trabalho infantil e sua inserção nas políticas do comércio exterior são indicativos da internacionalização de um problema social. A compreensão da exploração do trabalho infantil como algo vinculado às estruturas do capitalismo contemporâneo resultou na mobilização dos setores empresariais ligados às cadeias produtivas do agronegócio, no sentido do desenvolvimento de ações de responsabilidade social empresarial.

De acordo com Tenório (2004), desde as últimas décadas, o World Business Council for Suistainable Developement discute as concepções e o papel das empresas na construção do desenvolvimento sustentável. Sob o predomínio da ideologia neoliberal, essa instituição centralizou o debate em torno da responsabilidade social empresarial, que está associada ao desenvolvimento sustentável, compreendido sob as dimensões econômica, ambiental e empresarial. O objetivo das empresas que atuam sob esse prisma é obter o crescimento econômico, com preservação ambiental e respeito aos diversos agentes sociais envolvidos, para a melhoria das condições de vida da sociedade. A atuação com responsabilidade social garantiria às empresas o respeito e a confiança de todos os agentes envolvidos nas cadeias produtivas - produtores de bens e serviços, fornecedores, empregados, consumidores e comunidade em geral -, construindo um ciclo virtuoso nos negócios e sustentabilidade no longo prazo. A adoção, pelas empresas, de uma postura ética e responsável nos objetivos, nos compromissos e nos negócios, fortalece a legitimidade social de suas atividades, o que se reflete positivamente no conjunto de suas relações. A responsabilidade social empresarial requer, então, o cumprimento das disposições legais, o compromisso com o crescimento econômico e o envolvimento com atividades e programas comunitários, que visam ao aten- dimento dos compromissos com o desenvolvimento sustentável, com a melhoria da qualidade de vida de seus empregados, suas famílias e da comunidade em geral.

As atividades de responsabilidade social empresarial justificam-se, segundo Tenório (idem), pela forma instrumental, pelos benefícios e pelas pressões externas. A forma instrumental está associada às vantagens que podem ser alcançadas com o aumento da preferência pelos consumidores ou pela melhoria da imagem pública da empresa. A mobilização empresarial para a responsabilidade social também pode ser justificada pelos benefícios a serem auferidos em virtude das leis de incentivo fiscal, que reduz a carga tributária das empresas que se propõem a promover o desenvolvimento de regiões menos desenvolvidas (Lei n. 9 440, de 14 de março de 1997, que estimula a instalação de empresas nas regiões Norte, Nordeste e Centro-Oeste) e a incentivar projetos de atividades culturais ou esportivas (Lei Rounet, n. 8313 , de 23 de dezembro de 1991). Há empresas que justificam suas atividades de responsabilidade social por questões de princípios, construídos com base num conjunto de valores que fazem parte da cultura das organizações empresariais e orientam todas as relações com clientes, fornecedores, governo, acionistas, comunidades e meio ambiente. As pressões externas referem-se "às legislações ambientais, aos movimentos de consumidores, à atuação dos sindicatos em busca da elevação dos padrões trabalhistas, às exigências dos consumidores e às reivindicações das comunidades afetadas pelas atividades industriais" (idem, p. 33).

Não se pode desconsiderar que os processos de globalização também induziram o desenvolvimento de atividades de responsabilidade social empresarial. Para tanto, as ingerências das instituições internacionais, como a ONU e a OMC, tratam de estimular empresas de todo o mundo a adotar códigos de conduta e princípios básicos de respeito ao meio ambiente, de construção do desenvolvimento sustentável e de respeito dos direitos humanos já consagrados nas convenções e nos demais dispositivos de alcance internacional. Além disso, a OIT, por meio de normas e recomendações, procura referenciar todas as relações de trabalho reconhecidas internacionalmente, definindo os parâmetros de responsabilidade das empresas para com seus trabalhadores (KARKOTLI \& ARAGÃO, 2004; TENÓRIO, 2004). 
A partir das pressões internacionais e do desenvolvimento das concepções de responsabilidade social, pode-se compreender o envolvimento das empresas ligadas às cadeias produtivas do agronegócio na luta de prevenção e erradicação do trabalho infantil. Por um lado, a sustentabilidade, como valor social e ideal a ser atingido, implicou, dentre outros aspectos, no respeito e na solidariedade intergeracional, uma vez que as novas gerações são percebidas como o futuro da humanidade. Se não for garantido o desenvolvimento integral de todas as crianças, o futuro estaria comprometido. Por outro lado, o crescimento da pressão internacional, expresso nas contínuas ameaças de boicotes às mercadorias produzidas com uso do infantil e/ou com a super-exploração ou escravidão dos trabalhadores, induziu os empresários do agronegócio à adoção de certas práticas de responsabilidade social.

A mobilização dos setores empresariais instalados em território brasileiro foi uma iniciativa da Fundação Abrinq pelos Direitos da Infância, a fim de criar regras éticas mínimas para atuar num mercado cada vez mais competitivo e globalizado. Para tanto, os empresários foram estimulados a inserir cláusulas sociais nos contratos, a assinar pactos e aderir aos selos sociais, com o objetivo de eliminar o trabalho infantil nos diversos segmentos empresariais. De acordo com Santos (1996), a Fundação Abrinq surgiu, no final da década de 1980, no contexto da redemocratização do país e do crescimento dos movimentos sociais, dentre eles o movimento de luta pelos direitos das crianças e adolescentes ${ }^{2}$. A especificidade da Fundação Abrinq era mobilizar, conscientizar e engajar o segmento empresarial brasileiro, que até então mostrava-se alheio ou até mesmo avesso à luta pelos direitos humanos. No Sudeste do Brasil, região de maior desenvolvimento econômico, foi criada uma organização denominada Pensamento Nacional de Bases Empresariais, com o propó-

2 A Fundação Abrinq, criada pela Associação Brasileira dos Fabricantes de Brinquedos, define-se como uma instituição de direito privado, sem fins lucrativos, com a finalidade de "defender os direitos da criança em conformidade com as normas nacionais e internacionais", cuja missão é "sensibilizar e mobilizar a sociedade sobre as questões da infância, promovendo o engajamento social e empresarial em propostas para a solução dos problemas das crianças, através de ação política na defesa de seus direitos e através de ações exemplares que possam ser disseminadas e multiplicadas" (FUNDAÇÃO ABRINQ, 2007). sito de lutar pela redemocratização do país, construir um novo padrão de desenvolvimento e criar políticas de reajuste econômico, com dimensão mais humana e social.

Na primeira metade da década de 1990, a Fundação Abrinq contribuiu para a aprovação do ECA, participou de diversos programas de rádio e de televisão, escreveu artigos e reportagens em vários jornais de circulação nacional, promoveu diversas ações de mobilização e sensibilização da população e publicou livros e vídeos, visando à formação de uma consciência pública contra as formas perversas de uso do trabalho infantil. Para organizar e fortalecer as ações de erradicação do trabalho infantil, a Fundação Abrinq criou, em 1995, o Programa Empresa Amiga da Criança, com dois objetivos centrais: primeiro, estimular o compromisso das empresas para a não-utilização do trabalho infantil; segundo, incentivar e sugerir formas para contribuir para a formação das crianças e capacitação profissional dos adolescentes, dentro das mais diversas possibilidades. Dessa forma, para a Fundação Abrinq, a Empresa Amiga da Criança é aquela que não explora economicamente a força de trabalho infantil e desenvolve ações ou projetos de apoio à formação das crianças e à capacitação de adolescentes (FUNDAÇÃO ABRINQ, 2007).

Para alcançar os objetivos supracitados, a Fundação Abrinq estabeleceu três estratégias fundamentais: 1) a criação do selo Empresa Amiga da Criança; 2) a realização de uma campanha pela inclusão de pactos e de cláusulas sociais nos contratos, públicos e privados, de compras e venda de bens e serviços, para impedir a circulação de produtos e serviços com uso do trabalho infantil; 3) a mobilização social para fortalecer a capacidade normativa e fiscalizadora das instituições do Estado e da sociedade civil.

O selo Empresa Amiga da Criança é um diferencial concedido para as empresas que não empregam e nem são clientes de instituições que explorem a mão-de-obra infantil, o qual pode ser utilizado de diversos modos pelas empresas, inclusive nas embalagens dos seus produtos, material de divulgação ou peças publicitárias. O selo também pode significar que a empresa apóia ou financia projetos que envolvem crianças e adolescentes em situação de risco ou que parte da venda de algum artigo específico é investida em programas dirigidos para crianças. Ademais, com o selo, 
a empresa compromete-se a divulgar a legislação que versa sobre o emprego de crianças e adolescentes. Assim, a Fundação Abrinq percebe o selo Empresa Amiga da Criança como uma "espécie de ISO 9000", em alusão ao conjunto de normas da ISO, organização internacional que descreve um sistema de garantia de qualidade. Para a obtenção do diploma e do selo social, a empresa precisa comprometer-se, formal e publicamente, a não utilizar o trabalho infantil, conforme as determinações legais do país, a divulgar o compromisso assumido para sua cadeia de fornecedores e clientes e a desenvolver e apoiar algum programa social de formação das crianças ou de capacitação dos adolescentes. A validade do selo é de um ano, mas a empresa pode renovar o pedido da licença de utilização, por meio da reafirmação dos seus compromissos e das averiguações específicas (idem). De acordo com Santos (1996), o selo Empresa Amiga da Criança é utilizado, com maior freqüência, nas correspondências nacionais e internacionais, nas peças de publicidade das empresas, seja nos produtos, seja nos meios de comunicação escritos e eletrônicos, nos jornais, revistas, boletins e documentos de apresentação institucional.

Em 2007, a Fundação Abrinq havia concedido o selo Empresa Amiga da Criança a 1.049 empresas. Desse total, $783(74,6 \%)$ estavam estabelecidas na Região Sudeste, 132 (12,6\%) na Região Sul, 91 $(8,7 \%)$ na Região Nordeste, 35 (3,3\%) na Região Centro-Oeste e oito $(0,8 \%)$ na Região Norte. Somente no estado de São Paulo, 631 empresas aderiram ao selo, o que representava $59,2 \%$ do total das empresas cadastradas nessa Fundação (FUNDAÇÃO ABRINQ, 2007). Indubitavelmente, esses dados refletem as diferenças de desenvolvimento regional existente no país, com grande concentração empresarial nas regiões Sudeste e Sul, em detrimento das demais regiões do país.

Diversas empresas que integram cadeias produtivas do agronegócio demonstraram interesse pelo selo Empresa Amiga da Criança ${ }^{3}$. Nota-se que essas empresas não necessariamente atuam em apenas um setor de produção, seja na indústria de

3 Para efeitos da análise da adesão de setores do agronegócio ao selo social, foram considerados apenas a indústria de produção de máquinas, os equipamentos e insumos, o setor agrícola e a indústria de transformação agroindustrial. Para a tipificação dos setores que integram o agronegócio, tornou-se necessário fazer algumas adequações dos dados da Abrinq. produção, na agricultura, seja na agroindústria de transformação. As empresas têm uma atividade econômica principal, mas não raramente fazem investimentos em outros setores produtivos. Portanto, a diversificação dos investimentos em diferentes atividades econômicas representa certos problemas na definição do elo da cadeia produtiva do agronegócio, mas isso não impede de estabelecer uma aproximação da realidade.

Os dados da Abrinq indicam, contudo, que 13 indústrias que produzem insumos modernos para a agricultura obtiveram o selo social. Também vale mencionar que 25 indústrias metalúrgicas e cinco siderúrgicas, sediadas nos estados de São Paulo e Minas Gerais, obtiveram o selo da Abrinq. Na década de 1990, foram freqüentes as reportagens, nos meios de comunicação de massa, sobre o emprego de trabalho escravo e trabalho infantil que se somava ao rastro da destruição ambiental -, na produção de carvão vegetal, cujos mercados consumidores finais eram indústrias siderúrgicas e metalúrgicas. Em elos das cadeias produtivas desse carvão vegetal encontravam-se grandes indústrias produtoras de automóveis, máquinas, peças, implementos agrícolas e uma série de outros produtos de metais.

Apenas 15 empresas com atividades produtivas no setor agrícola aderiram ao selo social. As empresas desse setor empregam alta tecnologia para a produção de frutas, café, aves e hortaliças, bem como para o processamento agroindustrial e/ou classificação e embalagem, visando agregar valor aos seus produtos e atender às exigências do mercado exterior.

No ramo da agroindústria de processamento encontra-se um número considerável de empresas com o selo da Abrinq. Foi possível computar 76 que atuam na cadeia produtiva sucroalcooleira, 41 na cadeia de produtos alimentícios e de bebidas, cinco na cadeia de sucos cítricos, cinco na cadeia da indústria têxtil e três na cadeia de couros e peles.

A Fundação Abrinq também propôs a inserção de cláusulas sociais nos contratos comerciais de bens ou de serviços, firmados pelos diversos setores empresariais. Na essência, as cláusulas sociais nos contratos de comércio e de trabalho são compromissos assumidos pela empresa no sentido de combater a exploração do trabalho infantil na cadeia produtiva em que atuam, não adquirindo bens e/ou serviços de outras empresas que 
porventura tenham utilizado o trabalho de crianças ou de adolescentes. A inscrição de cláusulas sociais nos contratos comerciais implica na possibilidade jurídica de desobrigação de compra dos produtos e serviços, caso algum elo da cadeia produtiva tenha incorporado mão-de-obra infantil. Para implementar a experiência das cláusulas sociais, a Fundação Abrinq procurou mobilizar as empresas ou associação de empresas que tinham seus nomes relacionados como beneficiárias da exploração do trabalho infantil, de maneira especial a Associação Nacional dos Fabricantes de Veículos Automativos (Anfavea), a Associação Brasileira de Exportadores de Cítricos (Abecitrus) e a Petrobrás.

A assinatura de pactos de erradicação do trabalho infantil foi outra estratégia de mobilização dos setores sucroalcooleiro, citrícola, fumageiro e calçadista. Desde 1996, quando a Fundação Abrinq lançou a campanha de sensibilização empresarial, foram celebrados dez pactos, sendo sete vinculados ao setor sucroalcooleiro, sediados nos estados de São Paulo, Goiás, Mato Grosso do Sul, Minas Gerais, Paraná, Alagoas e Pernambuco. No Brasil, não é recente a vinculação do setor sucroalcooleiro à exploração do trabalho infantil, problema amplamente pesquisado por cientistas sociais (DOURADO, DABAT \& ARAÚJO, 1999; NEVES, 1999) e alvo de constantes denúncias públicas na televisão e na imprensa escrita (HUZAK \& AZEVEDO, 1994; MATEOS, 1996; CIPOLA, 2001). Não raras vezes, a Petrobrás, empresa que comporta capital estatal, tem comprado e subsidiado, com recursos públicos, as destilarias de álcool que direta ou indiretamente empregam a força de trabalho infantil. Contraditoriamente, o Estado-que deveria ser o fiel guardião dos direitos das crianças e dos adolescentes - torna-se beneficiário da exploração da mão-de-obra infantil.

Em linhas gerais, os pactos dos setores sucroalcooleiro, citrícola e fumageiro incluem compromissos das empresas em combater o uso da força de trabalho infantil, engajar os fornecedores de insumos e matérias-primas, apoiar as escolas públicas, investir nos fundos municipais dos direitos das crianças e adolescentes, construir parcerias com as organizações públicas e privadas para projetos educativos e profissionalizantes, dentre outros. Para exemplificar, o Pacto Goiás, firmado em 5 de novembro de 1999, que abrange as empresas do setor sucroalcooleiro do estado de Goiás, definiu os seguintes objetivos: "1) Recomendar à cadeia produtiva a eliminação de qualquer tipo de trabalho infantil, em quaisquer níveis, sempre observando o artigo sétimo, inciso XXXIII, referente à proibição do trabalho noturno, perigoso ou insalubre a menores de 18 anos, e de qualquer trabalho a menores de 16 anos, salvo na condição de aprendiz, a partir de 14 anos; 2) Incentivar ações que beneficiem a permanência das crianças na escola, melhoria da qualidade de ensino, capacitação profissional para adolescentes e complementação de renda para que as famílias mantenham os filhos na escola; 3) Recomendar às associadas a destinação aos fundos municipais de direitos da criança e do adolescente, prevista no Estatuto da Criança e do Adolescente e na legislação do imposto de renda; 4) Apoiar as iniciativas dos governos Federal, Estadual e Municipal e Ongs para a participação conjunta nas ações previstas no compromisso; 5) Colaborar no desenvolvimento de campanha para conscientização da importância do acesso e da permanência da criança brasileira na escola".

A assinatura de alguns pactos resultou de uma parceria entre as empresas do agronegócio e órgãos públicos responsáveis pelo combate à exploração da força de trabalho infantil. No caso específico do estado de Goiás, foram firmados dois pactos: um envolveu a Delegacia Regional do Trabalho (DRT-GO) e a empresa Arisco Industrial Ltda., e, o outro, a DRT-GO e o Sindicato das Indústrias da Alimentação no Estado de Goiás. Nota-se que a particularidade desses pactos foi a participação direta do poder público, por meio da DRT, que é vinculada ao Ministério do Trabalho. A assinatura desses pactos foi amplamente divulgada nos meios de comunicação, além de contar com a presença do Ministro do Trabalho e de autoridades públicas, apresentando-os à sociedade como algo de relevante valor social, de efetivação da justiça e de importância fundamental para o fim da exploração da criança.

Os pactos partem dos pressupostos lançados pela lei que interdita o trabalho infantil, bem como da máxima de que "um país que não cuida de suas crianças não tem futuro". Nos termos dos pactos, a resolução do trabalho infantil passa por dois caminhos. O primeiro diz respeito ao papel da DRT-GO na fiscalização dos fornecedores de matérias-primas, bem como no serviço de infor- 
mação para a Arisco Industrial Ltda. ou para o Sindicato das Indústrias Alimentícias, listando os produtores rurais autuados em flagrante. O segundo refere-se às agroindústrias de transformação de alimentos em seus papéis de orientar no estabelecimento de cláusulas nos contratos com os fornecedores de matérias-primas e nas convenções coletivas, a fim de efetivar a interdição do trabalho de menores de 14 anos. Nos pactos firmados, as indústrias comprometem-se a disponibilizar para a DRT-GO o nome e o endereço dos fornecedores contratados, com o objetivo de facilitar a fisscalização. Nessas condições, as entidades pactuantes indicam que, se existem problemas de exploração da força de trabalho infantil, a responsabilidade é dos fornecedores de matérias-primas: os produtores rurais. Por isso, devem ser fiscalizados e, se for o caso, denunciados e autuados, além da suspensão de contratos.

Os dois pactos mencionados demonstram a preocupação das agroindústrias em isolar o problema, situando-o pontualmente na produção agrícola propriamente e livrando-se de responsabilidades e de possíveis complicações legais diante dos casos de exploração do trabalho de crianças. Tal estratégia oculta, no entanto, que a produção agrícola é apenas um elo da cadeia produtiva do agronegócio, na qual as indústrias inserem-se numa posição de superioridade econômica, política e social. Vale ressaltar que são as agroindústrias que determinam os preços das matérias-primas pagos ao produtor rural, a cujo cálculo computam-se todas as despesas, inclusive as da mãode-obra empregada. Para as agroindústrias, interessa obter matérias-primas em quantidade satisfatória, de boa qualidade e a baixos preços, para que possam tornar-se competitivas e bem estabelecidas nos mercados nacional e internacional. Os preços estipulados para os produtos agrícolas são baixos, de maneira que, para a maioria dos agricultores, as margens de ganho são reduzidas. Na perspectiva dos produtores rurais, como seus rendimentos são limitados, interessa reduzir os custos com mão-de-obra assalariada. Por fim, no elo mais fraco dessa cadeia estão os pais, que precisam recorrer à solidariedade de seus filhos para aumentar o rendimento do trabalho.

Após as assinaturas dos Pactos de Erradicação do Trabalho Infantil e a intensificação das fiscalizações da DRT-GO, para não serem mais autuados, multados e processados, os produtores ru- rais não querem mais que os agenciadores de trabalhadores levem crianças e adolescentes para o trabalho. Chegam até a afirmar que a responsabilidade da arregimentação de trabalhadores infantis é dos agenciadores de trabalhadores assalariados, deixando, assim, de responder às irregularidades trabalhistas que, porventura, possam existir. Diante do problema, outra medida adotada pelos agricultores mais capitalizados foi a de intensificar a mecanização agrícola, como uma forma de substituir os trabalhadores pelas máquinas. Os agricultores menos capitalizados, em alguns casos, optaram pelo abandono dos plantios, noutras situações, preferiram produzir conforme os capitais existentes e os recursos humanos disponíveis na propriedade familiar.

\section{RESPONSABILIDADE SOCIALE SANÇÕES DOS MERCADOS GLOBALIZADOS}

Os investimentos em prêmios, selos e cerimônias de reconhecimento público, como proposto por instituições como a Fundação Abrinq, visam mobilizar o setor empresarial para o desenvolvimento de ações de responsabilidade social. $\mathrm{Na}$ essência, procuram dar visibilidade social e reconhecimento público àquelas empresas que se distinguem no desenvolvimento de ações em benefício das crianças. Em invés de punir práticas empresariais negativas, a Fundação Abrinq procura destacar aquelas que são socialmente responsáveis e envolvidas em projetos sociais em prol da infância. Sob a perspectiva das empresas, o primeiro motivo para a obtenção do diploma e do selo Empresa Amiga da Criança é o reconhecimento social, que possibilita maior divulgação e visibilidade dos programas que desenvolvem em prol das crianças e dos adolescentes. Dessa forma, o selo funciona como uma espécie de prêmio, ao mesmo tempo em que legitima e difunde as ações desenvolvidas no âmbito da responsabilidade social da empresa. O segundo motivo está relacionado ao propósito de melhorar a imagem da empresa, especialmente naquelas atividades produtivas que, de certa forma, estavam socialmente associadas aos problemas trabalhistas e ambientais, como é o caso do setor sucroalcooleiro. Assim, o selo torna-se uma estratégia de marketing social, na medida em que dá evidência à responsabilidade da empresa. O terceiro motivo refere-se ao atendimento das exigências dos consumidores. Os empresários estão percebendo que, no contexto internacional, há uma 
tendência de desenvolvimento de uma consciência dos consumidores no sentido de identificar a origem dos produtos disponibilizados no mercado para, então, consumir os produtos associados às empresas comprometidas com programas sociais e ambientais, em detrimento dos vinculados às empresas que exploram crianças ou degradam o meio ambiente.

Em face das medidas protecionistas e das sanções comerciais impostas pelos países que integram os grandes blocos econômicos, os setores empresariais aderiram às causas da infância e ao desenvolvimento do senso de responsabilidade social. Logo, muitas empresas trataram de transformar sua imagem perante a sociedade vinculando-se aos propósitos da erradicação do trabalho infantil em suas cadeias produtivas, usando esse vínculo, por sua vez, como um investimento em marketing social. Procuram ainda associar-se a uma visão mais humanitária de desenvolvimento, com respeito aos direitos sociais para garantir cidadania, inclusive para os segmentos sociais mais excluídos. Em suma, da perspectiva dos empresários, as principais razões para o engajamento na luta contra o trabalho infantil são: a mudança da imagem da empresa ou do setor perante a sociedade, o crescimento da produtividade e das relações comerciais, o desenvolvimento da consciência e exigência dos consumidores, a construção de um desenvolvimento humano e responsável socialmente. No contexto de competição dos mercados internacionais, os empresários querem distinguir-se da concorrência, que lhes parece desleal e desumana, promovida por empresários que aceitam ou praticam a exploração de seus trabalhadores.

Não se pode negar que a mobilização dos empresários ligados ao agronegócio, na luta contra o trabalho infantil, seja decorrente do aumento da pressão pela vinculação de normas de trabalho com a regulação internacional do comércio. As discussões que ocorrem na OMC, no GATT e no Tratado de Livre Comércio da América do Norte resultaram na inserção de cláusulas ditas sociais nos acordos internacionais do comércio, sendo que uma delas está relacionada à exploração da mãode-obra infantil. A cláusula social e o selo social seriam garantias de que determinado produto não use o trabalho infantil em sua fabricação, conferindo controle de qualidade de certos produtos que entram nos mercados internacionais. Assim, os códigos de trabalho, especialmente referentes ao trabalho infantil, entraram no campo das disputas comerciais existentes entre os países que compõem as grandes potências econômicas e os países em desenvolvimento. Deve-se concordar que o problema das crianças sensibiliza mais facilmente a opinião pública que os direitos dos trabalhadores em geral. Assim, as bandeiras de luta pelos direitos das crianças e dos adolescentes, levantadas pelos organismos internacionais desde a década de 1970 , foram progressivamente mencionadas como tema de uma cláusula social dentro do mercado internacional. A OMC e os Acordos do GATT, portanto, tratam de "defender os direitos dos trabalhadores", limitando suas prerrogativas apenas aos seus setores exportadores e passando por cima da OIT, do Unicef e da ONU, organizações que historicamente advogam a competência para atuar em todos os casos em que se configurar desrespeito dos direitos humanos e degradação dos direitos dos trabalhadores adultos e infantis (BONNET, 1998; 1999).

Em fóruns internacionais, as cláusulas sociais ou das normas sociais globais vêm recebendo sérias críticas, pois são vistas como novas formas de protecionismo comercial, representado sob uma roupagem humanitária. O Tribunal Internacional Independente do México Contra o Trabalho Infantil, realizado em 1996, denunciou que, no contexto de mercados globalizados, o trabalho infantil é transformado em pano de fundo das guerras comerciais entre os países, mas, de fato, o drama das crianças exploradas é o que menos interessa. Denunciou também que alguns países signatários do GATT e do Tratado de Livre Comércio da América do Norte não ratificaram a Convenção 138 da OIT, que versa sobre a idade mínima para a admissão de emprego. Ademais, a União Européia, em sua diretiva de 22 de junho de 1994, passou a autorizar o trabalho infantil e a generalização de "formações alternativas, o que na realidade nada mais é que a abertura para a antecipação do uso da força de trabalho infantil" (TRIBUNAL..., 1996).

No Brasil, o governo manifestou-se contra as restrições comerciais expressas na cláusula social da OMC, sob a alegação de que seria uma forma de discriminar os produtos originários dos países em desenvolvimento. Luiz Felipe Lampreia, embaixador e ministro brasileiro das Relações Exteriores, em artigo no jornal Folha de S. Paulo 
de 10 de novembro de 1996, fez críticas contundentes ao uso das cláusulas sociais como medida para garantir que os direitos trabalhistas estejam em conformidade com os padrões mundiais: "Padrões trabalhistas para regular o comércio internacional poderiam abrir o caminho para um semnúmero de medidas e práticas nitidamente protecionistas - inclusive unilaterais, a exemplo da utilização da famosa seção 301 da Lei de Comércio dos EUA, que já nos atingiu duramente, com sanções muito prejudiciais. Sendo mais difícil hoje ser abertamente protecionista, o protecionismo se traveste. O social se transforma em justificativa para proteção abusiva de setores que se sentem prejudicados pela concorrência de outros países" (LAMPREIA, 1996).

$\mathrm{Na}$ análise do representante do governo brasileiro, a definição de padrões trabalhistas, como forma de regular o comércio internacional, poderia criar uma infinidade de medidas e práticas protecionistas, para salvaguardar os interesses unilaterais dos países desenvolvidos. Atrás das motivações humanistas para evitar o uso predatório da mão-de-obra infantil, há uma preocupação de impedir que aquelas mercadorias produzidas no Terceiro Mundo representem concorrência às mercadorias produzidas pelos países ricos. Por tanto, não seria aceitável transformar a legítima preocupação da sociedade civil em novas formas de protecionismo.

A questão da inserção de cláusula social nos contratos comerciais internacionais é controversa. Para alguns, ela representa uma tentativa de evitar o dumping social, o que levaria a uma competição mais equilibrada. Para outros, no entanto, tal dispositivo representa a punição dos países mais pobres e a perpetuação do desequilíbrio entre as nações, uma vez que penaliza aqueles setores da produção voltados para a exportação. Os fatos indicam que, no Brasil, os produtos das indústrias de álcool, açúcar, cítricos, calçados e fumo tornaram-se alvo preferencial dos boicotes comerciais internacionais, ou seja, os produtos das cadeias produtivas que têm demonstrado maior competência no mercado internacional.

Assim, a mobilização dos setores empresariais vinculados ao agronegócio também está associada às ameaças dos boicotes aos seus produtos, nos novos contextos da economia globalizada. As possíveis restrições ao comércio internacional dentro da nova ordem econômica mundial aos produtos que porventura tenham incorporado trabalho infantil são os principais motivos da mobilização dos empresários. Todavia, não se pode negar que a mobilização contra o trabalho infantil não tenha aprimorado o senso de responsabilidade social dos empresários, no sentido da construção de um modelo de desenvolvido mais sustentável e da responsabilidade social com as novas gerações. Se as iniciativas adotadas pelo setor empresarial não apresentaram resultados significativos na resolução da problemática do trabalho infantil, ampliaram, todavia, o debate público e propiciaram um acúmulo de experiências.

Outra novidade da década de 1990 foi a entrada dos consumidores dos países desenvolvidos nesse movimento contra o trabalho infantil, por meio de ameaças ou da realização de boicotes de aquisição de produtos que tivessem denúncias de uso do trabalho infantil ou extrema exploração dos trabalhadores. Em campanhas educativas, os consumidores dos países desenvolvidos foram alertados de que poderiam consumir produtos fabricados por empresas que submetem os trabalhadores a condições aviltantes e, dessa forma, contribuírem para a exploração de crianças e adultos. Assim, alertou-se a respeito de produtos que careciam de informações sobre as condições de produção, para que os consumidores tivessem conhecimento da relação entre os produtos adquiridos e as relações sociais de trabalho existentes nos países exportadores (FALCONER \& FISCHER, 1999).

Nota-se que os consumidores utilizaram seu poder para impor certos princípios, para impedir a circulação de mercadorias importadas que tivessem incorporado o trabalho infantil. Desenvolvia-se, dessa maneira, uma espécie de publicidade negativa para informar ao público que aquele produto ou aquela marca fora fabricado com o uso do trabalho infantil. Isso se tornou um forte argumento para convencer as empresas a elaborar normas de conduta social e implementá-las não apenas nas matrizes, mas também nas filiais, em toda sua rede de empresas terceirizadas.

Assim, no contexto contemporâneo, há uma tendência de os consumidores retaliarem, por meio de boicotes ou de protestos, os produtos oriundos de empresas que não respeitam os direitos reconhecidos internacionalmente ou que degradam o meio ambiente. Refutando as vertentes teóricas que associam o consumo aos gastos inúteis ou 
irrefletidos, Canclini (2006, p. 59) afirma que "o consumo serve para pensar", na medida em que existe uma vinculação fundamentada entre consumo e cidadania. Para além do simples intercâmbio mercantil, o "consumo é o conjunto de processos socioculturais em que se realizam a apropriação e os usos dos produtos. Esta caracterização ajuda a enxergar os atos pelos quais consumimos como algo mais do que simples exercícios de gostos, caprichos e compras irrefletidas [...]" (idem, p. 60). Para o autor citado, o mercado não se constitui simplesmente num lugar para a realização de trocas de mercadoria, mas em espaço para as interações socioculturais complexas. Isso implica, segundo o autor, o reposicionamento do valor das mercadorias e do papel do mercado na sociedade, para entendê-los como construções sociais: "o valor mercantil não é uma coisa contida naturalisticamente nos objetos, mas é resultante das interações socioculturais em que os homens os usam" (idem, p. 70). Partindo de tais pressupostos, pode-se deduzir que, no consumo, os cidadãos pensam sua posição na sociedade e refletem sobre as práticas de quem produz e comercializa as mercadorias, bem como analisam os benefícios ou as perdas e os danos que as mercadorias podem causar a si próprios, à sociedade e ao meio-ambiente. Esses espaços e situações proporcionados pelo consumo tornam-se propícios para a reflexão e construção da cidadania. Assim, pode-se entender a intervenção crescente de consumidores que exigem ética na produção e circulação mercantil, preservação do meio ambiente, respeito aos direitos de reconhecidos internacionalmente e, vale ressaltar, recusa ao consumo de produtos que exploraram o trabalho de crianças.

\section{CONCLUSÕES}

Não restam dúvidas de que a mobilização dos setores empresariais vinculados às cadeias produtivas do agronegócio visa contornar as ameaças dos boicotes aos seus produtos no contexto da globalização da economia. As possíveis restrições, no comércio exterior do contexto da nova ordem econômica mundial, aos produtos que porventura tenham incorporado trabalho infantil, induziram a mobilização dos empresários. Por isso, os empresários das cadeias produtivas do agronegócio inseriram cláusulas sociais em seus contratos comerciais, assinaram pactos de erradicação do trabalho infantil e aderiram aos propósitos dos selos sociais, em razão do crescimento da pressão internacional, expressado por meio das contínuas ameaças de boicotes às mercadorias produzidas com exploração do trabalho de crianças e adolescentes. Essas iniciativas conferem legitimidade às empresas ligadas ao agronegócio nos mercados globalizados, além de constituírem-se em valiosos investimentos em marketing social.

Porém, não se pode desconsiderar que a mobilização dos empresários contra o trabalho infantil contribuiu para o aprimoramento do senso de responsabilidade social empresarial, no sentido da construção de um modelo de desenvolvimento sustentável. Se as iniciativas adotadas pelo setor empresarial não apresentaram resultados tão significativos na resolução da problemática do trabalho infantil, não se devem menosprezar a importância da ampliação do debate público e do acúmulo de experiências, que podem ser aprimoradas num processo de aprendizado contínuo. $\mathrm{O}$ resultado prático desse processo é o aumento de ações, políticas e programas, propostas por instituições públicas e privadas, para a proteção e desenvolvimento integral das crianças. Ou seja, os interesses econômicos das empresas e os interesses com o cuidado das futuras gerações, com os direitos das crianças ou com o futuro do país não são questões excludentes. O desenvolvimento econômico das empresas deve estar associado à responsabilidade social e transgeracional.

Portanto, a resolução do problema do trabalho infantil não deve restringir-se apenas à assinatura de pactos e cláusulas sociais, à adesão de um selo social ou à oferta de uma bolsa-família, ou ao encaminhamento das crianças às escolas. Deve-se, também, pensar-se na qualidade do ensino, na proposição de programas capacitação e de aprendizagem profissional para jovens e adultos. Isso significa pensar em programas que possam compensar, de uma forma ou de outra, aqueles ganhos proporcionados pelo trabalho da criança e do adolescente e criar oportunidades de qualificação profissional, tanto para os adultos quanto para as gerações futuras. Outro aspecto merecedor de reflexão é o fato de as indústrias preocuparem-se com a não-incorporação de trabalho infantil exatamente naqueles produtos que lhes são fornecidos. Sabe-se, porém, que, quando há adoção de medidas proibitivas do trabalho infantil em determinado produto, as crianças são incorporadas em 
outros serviços, muitas vezes com salários menores, em condições inseguras, insalubres ou mesmo comprometedoras de seu desenvolvimento moral.

Em suma, os programas de erradicação do trabalho infantil deveriam incluir em seu escopo a profissionalização dos jovens e adultos que integram a família da criança. Além disso, deveriam fortalecer as redes institucionais de apoio a grupos sociais, articulando ações conjuntas com empresas privadas, instituições estatais, organizações não-governamentais, associações comunitárias, culturais e religiosas. As cooperativas de produção, de crédito popular ou de outras formas de economia solidária deveriam encaminhar pais e mães às alternativas de inclusão social pelo trabalho. Faz-se necessário, enfim, forjar situações, espaços e tempos que contribuam para que crianças, adolescentes, jovens e adultos consigam superar as trilhas da desqualificação profissional, do desemprego ou do subemprego, seja na economia formal, seja na informal. A partir de processos participativos que contemplem a visão de mundo dos trabalhadores, devem emergir projetos de longo alcance que viabilizem a inclusão social e a constituição de novos sujeitos, partícipes do desenvolvimento histórico-social. Na construção desse projeto de desenvolvimento, não se pode desconsiderar a importância e a participação dos setores empresariais, sejam eles vinculados ou não às cadeias produtivas do agronegócio.

Joel Orlando Bevilaqua Marin (bevilaquamarin@gmail.com) é Doutor em Sociologia pela Universidade Estadual Paulista (Unesp) e Professor da Universidade Federal de Goiás (UFG).

\section{REFERÊNCIAS BIBLIOGRÁFICAS}

BEQUELLE, A. \& BOYDEN, J. 1990. Le enfant au travail. Paris : Fayard.

BOBBIO, N. 2004. A era dos direitos. Rio de Janeiro : Elsevier.

BONNET, M. 1998. Regards sur les enfants travailleurs. La mise au travail des enfants dans le monde contemporain : analise et étude de cas. Lausanne : Page Deux.

1999. Le travail des enfants : terrain de luttes. Lausanne : Page Deux.

CANCLINI, N. G. 2006. Consumidores e cidadãos : conflitos multiculturais da globalização. Rio de Janeiro : UERJ.

CIPOLA, A. 2001. O trabalho infantil. São Paulo : Publifolha.

DOURADO, A.; DABAT, C. \& ARAÚJO, T. C. 1999. Crianças e adolescentes nos canaviais de Pernambuco. In : DEL PRIORE, M. (org.). História das crianças no Brasil. São Paulo : Contexto.

FALCONER, A. P. \& FISCHER, R. M. 1999. O selo social contra o trabalho infantil : experiências brasileiras. Brasília : OIT.

HUZAK, I. \& AZEVEDO, J. 1994. Crianças de fibra. Rio de Janeiro : Paz e Terra.
KARKTLI, G. \& ARAGÃo, S. D. 2004. Responsabilidade social : uma contribuição à gestão transformadora das organizações. Petrópolis : Vozes.

LAMPREIA, L. F. 1996. Cláusula social no comércio internacional. Folha de S. Paulo, Tendências e Debates, 10.nov. Disponível em : http://ftp.unb.br/pub/UNB/ipr/rel/discmin/ 1996/3055.pdf. Acesso em : 14.dez.2009.

MARIN, J. O. B. 2005. Trabalho infantil : necessidade, valor e exclusão social. Goiânia : UFG.

MATEOS, S. B. 1996. Nossas crianças : sucata do progresso. Atenção, v. 1, n. 2.

MAZZALI, L. 2000. O processo recente de reorganização agroindustrial : do complexo à organização "em rede". São Paulo : UNESP.

MÉNDEZ, E. G. 1998. Infância e cidadania na América Latina. São Paulo : Hucitec.

MUNDT, M. F. 1998. Globalización y agricultura : escenarios controvérsias. In : CONGRESO LATINOAMERICANO DE SOCIOLOGÍA RURAL, 5., Texcoco, México. Anais... Texcoco : Alasru. 
NEVES, D. P. 1999. A perversão do trabalho infantil : lógicas sociais e alternativas de prevenção. Niterói : Intertexto.

OLIVEIRA, O. 1994 . O trabalho da criança e do adolescente. Brasília : OIT.

RODGERS, G. \& STANDING, G. 1983. Trabajo infantil, pobreza y subdesarrollo. Ginebra : OIT.

ROGALSKI, M. 1997. Clause sociale, emploi et commerce mondial. Recherches Internacionales, Paris, n. 50, aut. Disponível $\mathrm{em}: \mathrm{http}: / /$ www.gabrielperi.fr/Clause-socialeemploi-et-commerce. Acesso em : 21.nov.2009.

RUBIO, B. 2001. Explotados y excluidos : los campesinos latinoamericanos en la fase agroexportadora neoliberal. San Rafael, Mexico : Blanca Rubio.

SANTOS, B. R. 1996. Mobilização empresarial pela erradicação do trabalho infantil no Brasil : um estudo das estratégias desenvolvidas pela Fundação Abrinq pelos Direitos da Criança. São Paulo : Unicef.
SASTRE; B. C. \& MEYER, M. I. Z. 1996. Le travail des enfants dans les mines de charbon en Colombie. In : SCHLEMMER, B. (org.). L'enfant exploité : oppression, mise au travail, prolétarisation. Paris : Karthala.

SCHMIDT, C. A. J.; SOUSA, I. R. \& LIMA, M. A. M. 2006. Tipologias de dumping. Documento de trabalho. Rio de Janeiro: Secretaria de Acompanhamento Econômico. 12p. Disponível em : http://www.seae.fazenda.gov.br/ central_documentos/documento_trabalho/ 2002-1/doctrab17.pdf. Acesso em : 21.nov.2009.

SCHLEMMER, B. 1996. L'enfant exploité : oppression, mise au travail, prolétarisation. Paris : Karthala.

TENÓRIO, F. G. 2004. Responsabilidade social empresarial : teoria e prática. Rio de Janeiro : FGV.

TEUBAL, M. 1998. Globalización sus efectos sobre las sociedades rurales de América Latina. In : CONGRESO LATINOAMERICANO DE SOCIOLOGÍA RURAL, 5., Texcoco, México. Anais... Texcoco : Alasru.

\section{OUTRAS FONTES}

BRASIL. 1998. Trabalho infantil no Brasil : questões e políticas. Brasília : Presidência da República.

1999. Programa de erradicação do trabalho infantil : a área de Assistência Social. Brasília : Presidência da República.

FUNDAÇÃOABRINQ. 2007. Programa Empresa Amiga da Criança. São Paulo : Fundação Abrinq. Disponível em: http:// www.fundabrinq.org.br/portal/como-atuamos/ programas-e-projetos/programa-empresa-amiga-da-crianca/o-que-e.aspx. Acesso em: 21.nov.2009.

INTERNATIONAL CONFEDERATION OF FREE TRADE UNIONS. 1996. Pas le temps de jouer. Le travail des enfants dans l'économie mondiale. In : WORLD CONGRESS, 16. Brussels. Brussels : CIOSL. Disponível em : http://doc-aea.aide-et-action.org/data/admin/ pas_le_temps_de_jouer.pdf.

ORGANIZAÇÃO INTERNACIONAL DO TRABALHO. 1997. Le travail des enfants: l'intolérable en point de mire. Geneve : BIT.

TRIBUNAL INTERNACIONAL INDEPENDENTE DO MÉXICO CONTRA O TRABALHO INFANTIL. 1996. Boletim internacional de intercâmbio, Cidade do México, 22-24.mar.

UNICEF. 1997. La situation des enfants dans le monde. New York : Unicef. Disponível em : http://www.unicef.org/french/sowc97/ sowc97f3.pdf. Acesso em : 21.nov.2009. 


\section{AGROBUSINESS AND THE PROBLEM OF CHILD LABOR}

\section{Joel Orlando Bevilaqua Marin}

This article attempts to identify and analyze the motives that led several sectors of agro-business to engage in the struggle for the eradication of child labor in Brazil, as launched by international organizations for the defense of children's and adolescents' rights. It is our hypothesis that economic globalization and the internationalization of children's rights have given visibility to the problem of child labor, thus demanding the mobilization of entrepreneurial sectors linked to agro-business productive chains in Brazil. The article is divided into four inter-related sections. In the first one, we attempt to provide evidence for the interference of social and labor problems within the ambit of the economic activities of the agro-business sector, within the current context of globalization. This is followed by a study of major UN, UNICEF and ILO investments to internalize children's rights and policies to combat child labor, giving salience to their repercussions in Brazil. In the third section, we analyze strategies adopted by firms linked to agro-business with the purpose of avoiding the use of child labor within their productive chains. Finally, we seek to understand the motivations that have led agro-businessmen to take part in the struggle against child labor. We conclude that firms linked to agro-business took up the project of combating child labor in virtue of the internationalization of children and adolescents' rights, the inclusion of social issues in international markets, the intensification of the fiscalization of public power, the growth of action around entrepreneurial social responsibility and increased consumer consciousness.

KEYWORDS: agribusiness; globalization; child labor; children's rights; exploitation. 


\section{L'AGRO-ALIMENTAIRE ET LE PROBLÈME DU TRAVAIL DES ENFANTS}

\section{Joel Orlando Bevilaqua Marin}

L'article cherche à identifier et à analyser les raisons pour lesquelles certains secteurs de l'agroindustrie se sont engagés dans la lutte pour éradiquer le travail des enfants au Brésil, déclenchée par des organismes internationaux pour la défense des droits des enfants et des adolescents. Notre hypothèse est que la mondialisation économique et l'internationalisation des droits de l'enfant ont mis en évidence le problème du travail des enfants, ce qui a donc entraîné la mobilisation de secteurs industriels liés à la chaîne de production de l'agro-industrie au Brésil. L'article est divisé en quatre sections interdépendantes. Dans la première, nous cherchons à souligner l'interférence des problèmes sociaux et de travail dans les activités économiques de l'agro-business, dans le contexte actuel de la mondialisation. Ensuite, nous étudions les investissements les plus importants de l'Organisation des Nations Unies, l'UNICEF et l'Organisation internationale du travail visant à internaliser les droits des enfants et des politiques de lutte contre le travail des enfants, mettant en évidence son impact sur le Brésil. Dans la troisième section, nous analysons les stratégies adoptées par des sociétés liées à l'agro-industrie en vue d'empêcher l'exploitation de la main-d'oeuvre des enfants dans leurs chaînes de production.Enfin, nous cherchons à comprendre les motivations qui ont conduit les entrepreneurs de l'agro-industrie à se joindre à la lutte contre le travail des enfants. Il est conclu que les sociétés impliquées dans le secteur agroalimentaire se sont jointes aux fins de la lutte contre le travail des enfants en raison de l'internationalisation des droits des enfants et des adolescents, de l'inclusion de clauses sociales dans les marchés internationaux, de l'intensification du contrôle du pouvoir public, de la croissance des actions de responsabilité sociale des entreprises et de l'accroissement de la sensibilisation des consommateurs.

MOTS-CLES : agro-industries ; mondialisation, travail des enfants, droits de l'enfant, exploitation. 